\title{
Canopy structure, ingestive behavior and displacement patterns of beef heifers grazing warm-season pastures
}

\author{
[Estrutura do dossel, comportamento ingestivo e padrões de deslocamento de novilhas de \\ corte em pastagens de estação quente] \\ C.L. Glienke ${ }^{1}$, M.G. Rocha ${ }^{2 *}$, L. Pötter ${ }^{2}$, D. Roso $^{2}$, D.B. Montagner ${ }^{3}$, \\ R.A. Oliveira Neto ${ }^{4}$ \\ ${ }^{1}$ Universidade Federal de Santa Catarina - Campus Curitibanos, SC \\ ${ }^{2}$ Universidade Federal de Santa Maria - Santa Maria, RS \\ ${ }^{3}$ Embrapa Gado de Corte - Campo Grande, MS \\ ${ }^{4}$ Universidade Federal do Rio Grande do Sul - Porto Alegre, RS
}

\begin{abstract}
Analyses in a data set of six experiments $(n=436)$ was performed with the aim of characterizing canopy structure and forage intake patterns of beef heifers grazing on Pearl millet (Pennisetum americanum), Alexandergrass (Urochloa plantaginea) and Coastcross (Cynodon dactylon). Forage and leaf lamina mass were similar among species, 3001.4 and $668.1 \mathrm{~kg}$ of DM/ha, respectively, while leaf:stem ratio of canopy vertical strata was different. Intake rate $(12 \mathrm{~g} \mathrm{DM} /$ minute), bite mass $(0.343 \mathrm{~g} \mathrm{DM} / \mathrm{bite})$ and bite rate $(36.6 \mathrm{bites}$ per minute) were similar in Pearl millet and Alexandergrass. In Pearl millet, neutral detergent fiber content (56.1\%) in forage as grazed, grazing time (518.9 minutes/day) and displacement rate (8.8 steps/minute) were lower. Increased grazing time (639 minutes/day) represented the main compensatory mechanism for smaller bite masses $(0.234 \mathrm{~g} \mathrm{DM} / \mathrm{bite})$ and reduced intake rates $(8.8 \mathrm{grams}$ of $\mathrm{DM} /$ minutes $)$ in Coastcross. Bite rate variations happened as a response to constraints imposed by canopy structure. Surface utilization on Alexandergrass and Coastcross was increased by greater number of feeding stations visited and displacement rate. Ingestive behavior components of beef heifers are affected by differences in the canopy structure of Pearl millet, Alexandergrass and Coastcross.
\end{abstract}

Keywords: Cynodon dactylon, feeding station, grazing time, Pennisetum americanum, Urochloa plantaginea

\section{RESUMO}

Foi realizada a análise conjunta dos resultados de seis experimentos $(n=436)$ com o objetivo de caracterizar a estrutura do dossel e os padrões de ingestão de forragem por novilhas de corte em pastagem de milheto (Pennisetum americanum), papuã (Urochloa plantaginea) e coastcross (Cynodon dactylon). As massas de forragem e de lâminas foliares foram similares entre as três espécies forrageiras, 3001,4 e 668,1 kg/ha de MS, respectivamente, enquanto a relação lâmina:colmo do perfil vertical do dossel diferiu. A taxa de ingestão (12g MS/minuto), a massa de bocados (0,343g MS/bocado) e a taxa de bocados (36,6 bocados/minuto) foram similares no milheto e no papuã. O conteúdo de fibra em detergente neutro (56,1\%) na forragem da simulação do pastejo, o tempo de pastejo (518,9 minutos/dia) e a taxa de deslocamento (8,8 passos/minuto) foram menores no milheto. $O$ incremento no tempo de pastejo (639 minutos/dia) representou o mecanismo compensatório para a menor massa de bocados $(0,234 \mathrm{~g} \mathrm{MS} /$ bocado) e para a reduzida taxa de ingestão $(8,8$ gramas MS/minuto) no coastcross. Variações na taxa de bocado ocorrem como resposta às limitações impostas pela estrutura do dossel. A exploração da área da pastagem de papuã e de coastcross foi aumentada pelo maior número de estações alimentares visitadas e pela maior taxa de deslocamento. Os componentes do comportamento ingestivo de novilhas de corte são afetados por diferentes estruturas no dossel de milheto, papuã e coastcross.

Palavras-chave: Cynodon dactylon, estação alimentar, Pennisetum americanum, tempo de pastejo, Urochloa plantaginea

Recebido em 27 de fevereiro de 2015

Aceito em 15 de novembro de 2015

*Autor para correspondência (corresponding author)

E-mail: mgdarocha@gmail.com 


\section{INTRODUCTION}

Grazing activity is a highly complex process that involves characteristics of the herbivores and the sward structural composition. Age and body size, physiological and production level, and/or previous feeding status are some of the characteristics related to the herbivores (Delagarde et al., 2001). Likewise, the sward structural composition can be described based on characteristics such as canopy height, tiller density, canopy bulk density, vertical distribution of biomass and leaf lamina:stem ratio. These characteristics can vary according to the species utilized and grazing management during pasture utilization.

The grazing process requires the animal to manipulate the forage, to select and to harvest species with more nutritive value and/or plant components in order to supply the requirements for maintenance, growth and reproduction. Additionally, searching patterns and food prehension strategies of the herbivore are based on the canopy structure. These strategies involve changes in ingestive behavior components, such as bite frequency and grazing time, as well as the selection patterns of grazing places such as the number of feeding stations visited per minute.

Large vertical heterogeneity in bulk density, leaf percentage, and nutritive value are characteristics of many $\mathrm{C} 4$ grasses. From the hypothesis that this structural heterogeneity of tropical grasses influences ingestive behavior components, analyses on an experimental data set were performed. These analyses had the objective to characterize forage intake patterns by beef heifers grazing on Pearl millet (Pennisetum americanum (L.) Leeke), Alexandergrass (Urochloa plantaginea (Link.) R. D. Webster) and Coastcross (Cynodon dactylon (L.) Pers.).

\section{MATERIAL AND METHODS}

Data used in these analyses refer to 436 observations from six experiments held at Universidade Federal de Santa Maria (UFSM), Santa Maria-Brazil. The experiments were carried out between 2001 and 2010 and the most individual results can be found as scientific papers (Montagner et al., 2008; 2009; 2011; Costa et al., 2011; Souza et al., 2011; 2012; Oliveira Neto et al., 2013). The rearing of beef heifers was evaluated in Pearl millet (Penisetum americanum (L.) Leeke), Alexandergrass (Urochloa plantaginea (Link.) R. D. Webster) and Coastcross (Cynodon dactylon (L.) Pers) pastures. These studies used 355 beef heifers (Polled Hereford, Angus and crossbreed Charolais x Nelore), with an initial age of 14-15 months and body weight of $264.5 \pm 26.8 \mathrm{~kg}$.

The experimental area is located in the Central Depression of Rio Grande do Sul, Brazil, with latitude $29^{\circ} 43^{\prime}$ South and longitude $53^{\circ} 42^{\prime}$ West; the climate in the region is humid subtropical (Cfa), according to the Köppen classification. Pastures were established in a soil classified as Paleudalf (Sistema..., 2006). The mean values for the chemical characteristics of the soil were: $\mathrm{pH}-\mathrm{H}_{2} \mathrm{O}=4.8 ; \mathrm{Ca}^{2+}\left(\mathrm{cmol}_{\mathrm{c}} / \mathrm{dm}^{3}\right)=$ $5.6 ; \%$ clay $(\mathrm{m} / \mathrm{V})=19.0 ; \mathrm{OM}(\%)=2.8 ; \mathrm{P}$ $\left(\mathrm{mg} / \mathrm{dm}^{3}\right)=15.1 ; \mathrm{K}\left(\mathrm{mg} / \mathrm{dm}^{3}\right)=97.5$; saturation basis $(\%)=47.6$; Al saturation $(\%)=14.15$. In all experiments the average quantity of fertilizer consisted of $83.95 \mathrm{~kg} / \mathrm{ha}$ of $\mathrm{N}, 53 \mathrm{~kg} /$ ha of $\mathrm{P}$ and $53 \mathrm{~kg} / \mathrm{ha}$ of $\mathrm{K}$.

Coastcross was established in May 2006 and the area is mowed once annually in the spring. The annual pastures were established in November/December of each year after minimal soil preparation. Alexandergrass pasture was formed by an existing seed bank in the area. The areas were used for 129 days, on average, with 35 days to establish the annual pastures and 94 days of grazing by heifers. The grazing method was put-and-take stocking. Area replicates ranged from two to five, with three/four animaltesters per replication.

The forage mass was evaluated by the direct visual estimation method with double sampling (Gardner, 1986). The forage was cut at ground level and the botanical and structural components were separated manually into: leaf (blade), stem (leaf sheath + stem), dead material. The forage accumulation rate was estimated by using three exclusion cages located in each paddock. The canopy height, considered as the distance from the ground to the height of folding leaves $(\mathrm{cm})$, was measured with 20 readings in each experimental unit. The morphological composition per strata of sward (Stobbs, 1975) was evaluated on three areas of the sward in each experimental unit. The stocking adjustment was made through forage disappearance method 
(Heringer and Carvalho, 2002). The considered structural descriptors of the sward were: forage mass ( $\mathrm{kg}$ of DM/ha), leaf lamina mass and stem mass $(\mathrm{kg}$ of $\mathrm{DM} / \mathrm{ha})$, canopy height $(\mathrm{cm})$, forage accumulation rate $(\mathrm{kg}$ of $\mathrm{DM} / \mathrm{ha})$, forage allowance ( $\mathrm{kg} \mathrm{DM} / 100 \mathrm{~kg} \mathrm{BW})$, leaf lamina allowance (kg DM/100 kg BW) and average leaf lamina:stem ratio and per strata of the sward $(0-15 \mathrm{~cm} ; \quad 15-30 \mathrm{~cm} ; 30-45 \mathrm{~cm} ;>45 \mathrm{~cm})$. The leaf:stem ratio was calculated from the values of leaf lamina and stems in the sward vertical strata. In forage as grazed, the contents of crude protein $(\mathrm{CP}, \%)$ and neutral detergent fiber (NDF, \%) were evaluated.

Grazing, rumination and other activities (minutes/day), bite rate (bites/minute), bite mass (g DM/bite), intake rate (g DM/minute), number of feeding stations (stations/per minute), displacement rate (steps/minute), bites per feeding station, feeding station permanence time (seconds/station), steps between feeding stations and forage intake ( $\mathrm{kg} \mathrm{DM} /$ day) were the variables evaluated related to ingestive behavior. Grazing, rumination and other activities were measured by direct visual observation every 10 minutes for 24 hours. Intake rate was obtained from the product of mass and frequency of bites. Forage intake was estimated using chromic oxide as an external marker to estimate fecal production. The techniques used are described by Costa et al. (2011), Montagner et al. (2011) and Souza et al. (2011).

Statistical analyses were performed using the $\mathrm{R}$ software, version 2.12.2 (2011). The variables measured in the experiments were stratified as a function of the forage species. We performed a graphic analysis of the residues to verify linearity deviations and Shapiro-Wilk's normality test and also the Fligner-Killeen's test of homogeneity of variances. Whenever significant differences were found in both tests, non-parametric tests (Kruskal-Wallis and Wilkoxon), were used, as well as the Spearman's correlation test, at 5\% probability.

\section{RESULTS AND DISCUSSION}

Pastures were managed with similar values of forage and leaf lamina masses, and the leaf lamina mass represented $22.26 \%$ of forage mass (Tab. 1). In Pearl millet, the largest forage allowance and canopy height were verified, as well as the lowest stem mass, and these parameters were similar between Alexandergrass and Coastcross pastures.

Table 1. Structural and qualitative characteristics, forage and leaf lamina allowance and forage accumulation rate of warm-season pastures

\begin{tabular}{|c|c|c|c|c|c|c|}
\hline \multirow{2}{*}{ Variables } & \multicolumn{3}{|c|}{ Species } & \multirow{2}{*}{ Mean } & \multirow{2}{*}{$\mathrm{P}^{1}$} & \multirow{2}{*}{$\mathrm{SD}^{2}$} \\
\hline & P. millet & Alexandergrass & Coastcross & & & \\
\hline Forage mass $^{3}$ & 2993.5 & 3065.8 & 2944.9 & 3001.4 & 0.9350 & 956.9 \\
\hline Leaf lamina mass ${ }^{3}$ & 661.1 & 705.2 & 637.9 & 668.1 & 0.0797 & 256.3 \\
\hline Stem mass $^{3}$ & $1449.4 b$ & $1673.9 \mathrm{a}$ & $1703.2 \mathrm{a}$ & 1703.2 & 0.0134 & 528.2 \\
\hline Forage allowance $^{4}$ & $13.4 \mathrm{a}$ & $11.3 \mathrm{~b}$ & $11.0 \mathrm{~b}$ & 11.9 & $<0.0001$ & 3.7 \\
\hline $\operatorname{LLA}^{4,5}$ & $4.4 \mathrm{a}$ & $2.8 \mathrm{~b}$ & $1.8 \mathrm{c}$ & 3,0 & $<0.0001$ & 2.8 \\
\hline Forage accumulation rate $^{3}$ & $186.2 \mathrm{a}$ & $107.7 \mathrm{~b}$ & $84.2 \mathrm{c}$ & 126.0 & $<0.0001$ & 94.6 \\
\hline Average LS ratio ${ }^{6}$ & 0.57 & 0.51 & 0.39 & 0.49 & 0.6128 & 0.4 \\
\hline LSR $0-15 \mathrm{~cm}$ & $0.51 \mathrm{a}$ & $0.30 \mathrm{~b}$ & $0.15 \mathrm{c}$ & 0.32 & $<0.0001$ & 0.3 \\
\hline LSR $15-30 \mathrm{~cm}$ & $1.64 \mathrm{a}$ & $0.58 \mathrm{~b}$ & $0.41 b$ & 0.88 & 0.0002 & 1.8 \\
\hline LSR $30-45 \mathrm{~cm}$ & $2.15 \mathrm{a}$ & $0.57 b$ & $1.72 \mathrm{a}$ & 1.47 & $<0.0001$ & 3.1 \\
\hline $\mathrm{LSR}>45 \mathrm{~cm}$ & $1.69 \mathrm{a}$ & $0.51 b$ & - & 1.10 & $<0.0001$ & 1.2 \\
\hline Canopy height $^{7}$ & $26.1 \mathrm{a}$ & $19.3 b$ & $19.7 \mathrm{~b}$ & 21.7 & $<0.0001$ & 9.4 \\
\hline $\mathrm{NDF}^{8}$ & $56.1 \mathrm{c}$ & $66.9 \mathrm{~b}$ & $72.2 \mathrm{a}$ & 65.06 & $<0.0001$ & 9.1 \\
\hline Crude protein $^{9}$ & $14.4 \mathrm{a}$ & $14.3 \mathrm{a}$ & $12.5 b$ & 13.8 & 0.0016 & 3.3 \\
\hline
\end{tabular}


The highest stem mass observed in Alexandergrass and Coastcross corresponded to $56.2 \%$, on average, of the forage mass, and in Pearl millet, the stem mass contributed $48.4 \%$ of the forage mass (Table 1). Leaf lamina allowance (LLA) was $36.4 \%$ higher in Pearl millet than in Alexandergrass and $35.7 \%$ higher in Alexandergrass compared to Coastcross. This difference observed in both LLA and forage allowance is due to the stocking rate adjustment method used. In these adjustments, the forage accumulation rate (GR) considered was different among forage species (Table 1). The high accumulation rate observed in Pearl millet is a hallmark of this species that is able to produce high amounts of forage in a short period of time. Forage accumulation rate is influenced by factors such as nutrient availability, humidity, temperature and photoperiod. In Coastcross, as a perennial species, tillering is an ongoing process that takes place along the plant lifespan and there are different priorities in the allocation of assimilates in relation to annual species. On the other hand, for herd management, the lower forage accumulation rates of Coastcross during the evaluation period can be compensated by the possibility to extend its utilization in a favorable environmental condition, such as an autumn with mild temperatures and no frost.

The average leaf:stem ratio (LSR) of the sward was similar among the three species (Tab. 1). Despite having similar amount of leaf lamina in the sward, which provided similar average leaf:stem ratio between species, the proportion of these leaves in relation to stem differed between species in the sward vertical strata. The LSR is linked to plant growth form, which affects the vertical distribution of structural components, and can be modified by management. For Pearl millet and Alexandergrass, which are annual species, its forage production is strongly linked to stem production, especially in the reproductive stage when they stop emitting new leaves. Pearl millet has an upright growth habit, with high elongation of internodes, while Alexandergrass has a decumbent growth habit, characterized by an initial stoloniferous growth, then erect. On the other hand, Coastcross is a prostrate stoloniferous perennial grass with erect to decumbent stems with rooting points and vertical growth of the leaves. In addition, the growth pattern of stems does not depend on phenological stages, such as the reproductive stage (Carvalho et al., 2000).

In Pearl millet the highest values of leaf:stem ratio in all strata of the sward were observed, except in the $30-45 \mathrm{~cm}$ stratum, where the leaf:stem ratio was similar to the observed value in Coastcross. This higher value of leaf:stem ratio observed in Coastcross is associated to the continuous leaf emergence, characteristic of perennial species. These new leaves appear in the upper strata. The stratum above $45 \mathrm{~cm}$ was not evaluated in this species probably due to its growth habit which differs from the upright growth habit of Pearl millet and Alexandergrass.

The leaf:stem ratio is an important parameter to consider towards a better understanding of the ingestive behavior and herbage intake of animals, because the proportion and also the arrangement of leaves in the canopy influence the harvesting ease and chemical composition of forage as grazed. High LSR represents availability of forage with a higher $\mathrm{N}$ content and digestibility for the herbivore. In forage species with tender and less lignified stems, such as Alexandergrass, this characteristic may have less relevance. This component offers less resistance to breaking while the herbage is harvested and less quality impairment of the forage as grazed when stems and leaf lamina are captured together.

The high basal tillering, higher leaf:stem ratio and high density of green leaves in Pearl millet under continuous grazing are obtained when the canopy is managed with an average height of $30 \mathrm{~cm}$, and it can be considered as a recommendation of management for this species (Moojen et al., 1999). This value is close to that observed in the database studies (Tab. 1), indicating that the heifers were kept in Pearl millet under favorable conditions for grazing.

The neutral detergent fiber (NDF) content in Pearl millet is within the range of $55-60 \%$ considered by Van Soest (1994) as limiting for forage intake. This value in the forage as grazed was lower, probably due to the greater leaf blade allowance and high leaf:stem ratio in the upper strata (Tab. 1). In Alexandergrass and Coastcross, the NDF content was higher than this limit. This fact would explain partially, for the three forages, the deficit in DM intake in relation 
to estimated values (Nutrient..., 2000) for animals of this category (Tab. 2). For Coastcross, the greatest NDF content is accompanied by the lowest DM intake, without differing from Pearl millet (Table 1). An increase of retention time of the digest in the rumen, causing a reduction in DM intake, is observed when diets have a high concentration of NDF (Nutrient..., 1996).

The crude protein $(\mathrm{CP})$ content in the forage as grazed was similar for Pearl millet and
Alexandergrass (Table 1). In the three species, the $\mathrm{CP}$ content in the forage harvested by the heifers exceeded about 1.7 times the amount of $8 \%$, considered limiting to forage intake (Van Soest, 1994). These values are also higher than the average CP content of $9.9 \%$, observed by Euclides et al. (1999) for three cultivars of Panicum maximum used in tropical regions in Brazil. This result demonstrates the high CP content of tropical forage species used in southern Brazil.

Table 2. Forage intake, ingestive behavior and selection patterns of grazing places by beef heifers in warm-season pastures

\begin{tabular}{|c|c|c|c|c|c|c|}
\hline \multirow{2}{*}{ Variables } & \multicolumn{3}{|c|}{ Forage species } & \multirow{2}{*}{ Mean } & \multirow{2}{*}{$\mathrm{P}^{1}$} & \multirow{2}{*}{$\mathrm{SD}^{2}$} \\
\hline & P. millet & Alexandergrass & Coastcross & & & \\
\hline Forage intake ${ }^{3}$ & $6.1 \mathrm{ab}$ & $6.5 \mathrm{a}$ & $5.6 \mathrm{~b}$ & 5.6 & 0.0226 & 1.5 \\
\hline Bite mass ${ }^{4}$ & $0.343 \mathrm{a}$ & $0.342 \mathrm{a}$ & $0.234 b$ & 0.234 & $<0.0001$ & 0.1 \\
\hline Bite rate ${ }^{5}$ & $35.8 b$ & $37.4 \mathrm{~b}$ & $40.3 \mathrm{a}$ & 40.26 & 0.0004 & 8.3 \\
\hline Intake rate ${ }^{6}$ & $12.0 \mathrm{a}$ & $12.0 \mathrm{a}$ & $8.8 b$ & 8.8 & $<0.0001$ & 3.7 \\
\hline Grazing time $^{7}$ & $518.9 \mathrm{c}$ & $559.5 b$ & $639.0 \mathrm{a}$ & 639.0 & $<0.0001$ & 92.6 \\
\hline Rumination time $^{7}$ & 468.0 & 475.0 & 435.3 & 459.4 & 0.2171 & 86.8 \\
\hline Other activities ${ }^{7}$ & $423.2 \mathrm{a}$ & $404.7 \mathrm{~b}$ & $366.1 \mathrm{~b}$ & 398.0 & 0.0256 & 110.1 \\
\hline Bites per station & 6.2 & 7.1 & 7.0 & 7.0 & 0.0699 & 2.2 \\
\hline Time per station ${ }^{8}$ & 11.8 & 11.6 & 10.4 & 11.5 & 0.0741 & 3.4 \\
\hline Steps between stations ${ }^{9}$ & 1.7 & 1.8 & 1.6 & 1.7 & 0.1712 & 0.5 \\
\hline Feeding stations ${ }^{10}$ & $5.4 \mathrm{c}$ & $6.1 \mathrm{~b}$ & $6.6^{\mathrm{a}}$ & 6.6 & 0.0026 & 1.7 \\
\hline Displacement rate $^{11}$ & $8.8 \mathrm{~b}$ & $10.40 \mathrm{a}$ & $10.5^{\mathrm{a}}$ & 10.5 & 0.0245 & 3.6 \\
\hline
\end{tabular}

${ }^{1}$ Probability; ${ }^{2}$ Standard deviation; ${ }^{3} \mathrm{~kg}$ of DM/animal; ${ }^{4} \mathrm{~g}$ DM/bite; ${ }^{5}$ bites/minute; ${ }^{6}$ grams of DM/minute; ${ }^{7}$ minutes/day; ${ }^{8}$ seconds/feeding station; ${ }^{9}$ steps between feeding stations; ${ }^{10}$ feeding station/minute, ${ }^{11}$ steps/minute. Different letters within lines differ according Kruskal-Wallis test.

Forage intake was greater in Alexandergrass than in Coastcross, while in Pearl millet the intake was intermediary and did not differ from the other species (Tab. 2). In proportion of body weight, forage intake corresponded to $2.08,2.15$, and $1.81 \%$ for heifers on Pearl millet, Alexandergrass and Coastcross, respectively. The daily forage intake estimated for this category is $2.7 \%$ of body weight (Nutrient..., 2000) and corresponds to $6.9 \mathrm{~kg}$ of DM. Thus, it is possible to attribute a deficit in the quantity of forage consumed by the heifers of 11.6, 5.8 and $18.8 \%$ for Pearl millet, Alexandergrass and Coastcross, respectively. Besides the values observed in these experiments, evaluations of DM intake of cattle on tropical species (Euclides et al., 1999; Cândido et al., 2005) have obtained inferior values than the ones predicted by NRC (Nutrient..., 2000). It can suggest that, considering the particular condition of these trials with tropical species, the values of DM intake estimated by NRC are overestimated for the gain range observed for these beef heifers.

Dry matter intake is the result of the amount of forage apprehended in each bite and the frequency of prehension movements in a time length. In this context, the lower forage intake in Coastcross was resultant of the lower bite mass (Table 2) that was $22 \%$ inferior to the critical value reported in bibliography, of $0.3 \mathrm{~g} \mathrm{DM} /$ bite, considering animals grazing on tropical pastures (Stobbs, 1974). In Pearl millet and Alexadergrass $(\mathrm{P}>0.05)$ bite mass was close to this limit value found in bibliography. Hirata et al. (2010) observed bite mass values between 0.2 and $1.6 \mathrm{~g}$ DM with cattle grazing stoloniferous centipede grass (Eremochloa ophiuroides (Munro) Hack.) and Paspalum notatum Flügge.

The increase in the sward height, in annual species, could have represented the decrease in the leaf lamina bulk density, hindering heavier 
bites. This effect can even be explored through the variation of leaf:stem ratio in the sward vertical strata. It points to the fact that the bites were concentrated in the strata with greater LSR, $30-45 \mathrm{~cm}$ in Pearl millet, and $15-45 \mathrm{~cm}$ in Alexandergrass (Tab. 1).

Bite mass in Coastcross was associated with leaf blade mass $(\rho=0.41$; $\mathrm{P}=0.0458)$ and with the forage as grazed chemical composition (CP: $\quad \rho=0.42$; $\mathrm{P}=0.0422$; NDF: $\rho=-0.51 ; \mathrm{P}=0.0102)$. The positive correlation points to animal selectivity for leaves, highest quality component in warmseason forage species. On the other hand, the high levels of NDF in forage as grazed and the negative correlation between this trait and bite mass indicate that the low values of leaf:stem ratio and the great stem mass (Table 1) could have limited the formation of bites with greater mass, due to difficulty in harvesting leaves.

A negative correlation between bite mass and bite rate was observed in Pearl millet $(\rho=-0.70$; $\mathrm{P}<0.0001)$ and Alexandergrass $\quad(\rho=-0.49$; $\mathrm{P}<0.0001$ ). This negative association shows the increase in the manipulative movements that follow the increase in bite mass (Hodgson et al., 1997), since bites with greater mass demand major processing in comparison to smaller ones.

The observed values of bite rate, 20 to 50 bites/minute, were situated within the range of results with tropical grasses (Brâncio et al., 2003; Palhano et al., 2007). In limiting situations, growing cattle can achieve rates up to 70 bites/minute (Delagarde et al., 2001). This fact, associated with the nonexistent correlation between bite rate and bite mass in Coastcross, in which the lower bite mass and the greater bite rate were observed, shows that the bite rate response, in this species, did not reflect the possible limitations on forage intake, as previously discussed. Thus, the bite rate variation, more than an attempt of the animal to compensate variation in bite mass, was a direct response to modifications in the sward structure, as already summarized and discussed by Galli et al. (1996).

Bite rate was negatively correlated with LSR in the stratum $>45 \mathrm{~cm}(\rho=-0.63 ; \mathrm{P}=0.0015)$ in Alexandergrass. The canopy architecture in Alexandergrass would possibly facilitate the access of the heifers to the top stratum, allowing the animals to perform bites with greater mass, reducing its frequency. On the other hand, the searching for leaf lamina during grazing and the difficulty in its prehension can happen even when there is a great availability of leaf lamina, since they can be found in a dispersed way in the canopy. This could explain a positive correlation between bite rate and leaf lamina mass $(\rho=0.54$; $\mathrm{P}=0.0067)$ and with average leaf:stem ratio $(\rho=0.56 ; P=0.0041)$ in Coastcross. The major presence of leaf lamina in the bottom strata increases the frequency of the bites, due to possible barriers to grazing represented by the greater proportion of stems and presence of dead material in this place of the canopy. This way, bite rate responds mainly to limitations to bite formation imposed by the reduction in leaf lamina accessibility.

The product between bite mass and its frequency results in the speed in which the animal consumes the forage. The values of intake rate in Pearl millet and Alexandergrass (Table 2) are within the range considered for young cattle, of 10-25g DM/minute (Delagarde et al., 2001). In Coastcross, however, the intake rate is $11.6 \%$ under the minimum limit suggested by this author. On the other hand, Palhano et al. (2007) observed values ranging from 7.5 to $17.0 \mathrm{~g}$ $\mathrm{DM} /$ minute for cattle grazing on Panicum maximum Jacq. cv. Mombaça with 60 and $140 \mathrm{~cm}$ of sward height. Galli et al. (1996) stated that when bite mass decreases there is an increase in bite rate because of the lower mastication time required, but as there is a 'fixed cost', represented by the apprehension time, the intake rate is reduced. This mechanism would explain why bite rate does not have the necessary compensatory effect to maintain the speed of intake when there is a reduction in the bite mass, as observed in Coastcross.

A strategy adopted by grazing animals, when the speed of consumption is reduced, is to increase grazing time, in order to maintain the level of DM intake constant. In Coastcross, the grazing time observed was of 19 and $12 \%$ superior to the observed in Pearl millet and Alexandergrass, respectively (Table 2). According to Galli et al. (1996), beef cattle can reserve 4 to 14 hours per day for grazing activity, and the animals can extend the grazing time when the intake rate is reduced by a decrease in available forage. This 
was verified in Coastcross with the heifers grazing around 11 hours per day, with the lowest forage allowance of $11 \mathrm{~kg} \mathrm{DM} / 100 \mathrm{~kg} \mathrm{BW}$ and leaf blade allowance of $1.8 \mathrm{~kg} \mathrm{DM} / 100 \mathrm{~kg} \mathrm{BW}$. Muscular fatigue of the jaw and the energetic cost to search for forage are factors that influence the time spent by the animal in grazing activity along the day (Prache and Peyraud, 2001). Additionally, the flexibility to increase the grazing time ends when other activities are performed by the animal during the day, such as rumination and idling (Chacon and Stobbs, 1976). As the time dedicated to rumination was similar in the three forage species (Table 2), the compensation to variation in the grazing time happened through the idling time, which was lower in Coastcross and Alexandergrass and higher in Pearl millet.

During grazing activity, the number of bites per feeding station, the time remaining in the same station and the number of steps between each station were similar among the three species (Tab. 2). The permanence of the animals in each feeding station is connected to the quantity and quality of the available forage and adjustments in the displacement and forage searching patterns are a response to canopy structure. The relationship between selection of grazing patches and canopy structure was verified in the greater number of feeding stations per minute visited in Coastcross (Table 2) in relation to the heifers in Pearl millet and Alexandergrass. There was a correlation of number of feeding station with LSR of $30-45 \mathrm{~cm}$ stratum $(\rho=0.88 ; \mathrm{P}=0.0213)$ and canopy height $(\rho=0.44 ; \quad \mathrm{P}=0.0015)$ in Coastcross. These correlations show that more important than the total availability of forage or the presence of leaf lamina is the proportion of leaf lamina allowance and the vertical architecture of the sward (Griffiths et al., 2003). According these authors, the spatial distribution of leaf lamina was more important than leaf lamina mass, highlighting the importance of the structural composition of the grazed horizon.

In Pearl millet, heifers visited fewer feeding stations per minute with lower displacement rate
(Table 2). There was a positive correlation between displacement rate and LLA in Pearl millet $(\rho=0.51 ; \quad \mathrm{P}=0.0008), \quad$ Alexandergrass $(\rho=0.46 ; \quad P<0001)$ and Coastcross $(\rho=0.41$; $\mathrm{P}=0.0458)$. There was also a correlation with leaf lamina mass in Coastcross $(\rho=0.46 ; P=0.0237)$ and Alexandergrass $(\rho=0.43 ; \mathrm{P}<0001)$. From these correlations, it is possible to observe that the searching for leaf lamina in canopy influenced the displacement of the animals. In Alexandergrass, the leaf lamina probably showed low accessibility, characterized by the low leaf:stem ratio and high stem mass, justifying the elevated displacement rate and number of feeding stations visited in this specie. This hypothesis was supported in Coastcross due to the high correlation of feeding stations visited per minute with leaf:stem ratio in the upper strata, and the correlation of displacement rate with leaf lamina mass. The modification in the displacement speed can raise the chances to find better grazing patches during the activities related to searching for forage (Prache et al., 1998), which can be seen as a strategy of the animals to increase the exploitation of the area in Alexandergrass and Coastcross.

\section{CONCLUSIONS}

In Pearl millet, Alexandergrass and Coastcross with similar leaf lamina mass, the accessibility to these leaves and the proportion of this component in relation to other components of the forage mass influence the feeding behavior of beef heifers. In Alexandergrass, heifers respond with an increase in the grazing time and in the number of feeding stations visited per minute, keeping the same bite mass and intake rate in comparison to heifers in Pearl millet. The variation in the bite rate is a response to the constraints imposed by the canopy structure. The increase in grazing time is the main compensatory mechanism among feeding behavior components facing a low bite mass and reduced intake rate in Coastcross, resulting from the low leaf lamina allowance and high participation of stems in the strata that are accessible to animals in this species. 


\section{REFERENCES}

BRÂNCIO, P.A.; EUCLIDES, V.P.B.; NASCIMENTO JUNIOR, D. et al. Avaliação de três cultivares de Panicum maximum Jacq. sob pastejo: comportamento ingestivo de bovinos. Rev. Bras. Zootec., v.32, p.1045-1053, 2003.

CÂNDIDO, M.J.D.; ALEXANDRINO, E.; GOMIDE, C.A.M. et al. Período de descanso, valor nutritivo e desempenho animal em pastagem de Panicum maximum cv. Mombaça sob lotação intermitente. Rev. Bras. Zootec., v.34, p.1459-1467, 2005.

CARVALHO, C.A.B.; SILVA, S.C.; SBRISSIA, A.F. et al. Demografia de perfilhamento e taxas de acúmulo de matéria seca em capim "tifton 85 " sob pastejo. Sci. Agric., v.4, p.591-600, 2000.

CHACON, E.; STOBBS, T.H. Influence of progressive defoliation of a grass sward on the eating behaviour of cattle. Aust. J. Agric. Res., v.27, p.709-727, 1976.

COSTA, V.G.; ROCHA, M.G.; POTTER, L. et al. Comportamento de pastejo e ingestão de forragem por novilhas de corte em pastagens de milheto e papuã. Rev. Bras. Zootec., v.40, p.251259, 2011.

DELAGARDE, R.; PRACHE, S.; D'HOUR P. et al. Ingestion de l'herbe par les ruminants au pâturage. Fourrages, v.166, p.189-212, 2001.

EUCLIDES, V.P.B.; THIAGO, L.R.S.; MACEDO, M.C.M. et al. Consumo voluntário de forragem de três cultivares de Panicum maximum sob pastejo. Rev. Bras. Zootec., v.28, p.1177-1185, 1999.

GALLI, J.R.; CANGIANO, C.A.; FERNÁNDEZ, H.H. Comportamiento ingestivo y consumo de bovinos en pastoreo. Rev. Arg. Prod. Anim., v.16, p.119-142, 1996.

GARDNER, A.L. Técnicas de pesquisa em pastagens e aplicabilidade de resultados em sistemas de produção. Brasília: IICA, 1986. 197p.

GRIFFITHS, W.M.; HODGSON, J.; ARNOLD, G.C. The influence of sward canopy structure on foraging decisions by grazing cattle. I. Patch selection. Grass Forage Sci., v.58, p.112-124, 2003.
HERINGER, I.; CARVALHO, P.C.F. Ajuste da carga animal em experimentos de pastejo: uma nova proposta. Cienc. Rural, v.32, p.675-679, 2002.

HIRATA, M.; KUNIEDA, E.; TOBISA, M. Short-term ingestive behaviour of cattle grazing tropical stoloniferous grasses with contrasting growth forms. J. Agr. Sci., v.148, p.615-624, 2010.

HODGSON, J.; COSGROVE G.P.; WOODWARD, S.J.R. Research on foraging behaviour: progress and priorities. In: INTERNATIONAL GRASSLAND CONGRESS, 18 ., 1997. Proceedings... Winnipeg: IGC, 1997. p.681-689.

MONTAGNER, D.B.; ROCHA, M.G.; GENRO, T.C.M. et al. Sward structural characteristics and ingestive behavior of beef heifers in a Pearl Millet pasture. Rev. Bras. Zootec., v.38, p.16681674, 2009.

MONTAGNER, D.B.; ROCHA, M.G.; GENRO, T.C.M. et al. Ingestão de matéria seca por novilhas de corte em pastagem de milheto. Cienc. Rural, v.41, p.686-691, 2011.

MONTAGNER, D.B.; ROCHA, M.G.; SANTOS, D.T. et al. Manejo da pastagem de milheto para recria novilhas de corte. Cienc. Rural, v.38, p.2293-2299, 2008.

MOOJEN, E.L.; RESTLE, J.; LUPATINI, G.C. et al. Produção animal em pastagem de milheto sob diferentes níveis de nitrogênio. Pesqui. Agropecu. Bras., v.34, p.2145-2149, 1999.

NUTRIENT requirement of beef cattle. 7.ed. Washington: National Academy Press, 1996. 90p.

NUTRIENT requirement of beef cattle. 7.ed. Washington: National Academy Press, 2000. 248p.

OLIVEIRA NETO, R.A.; DA SILVA, J.H.S.; ROCHA, M.G. et al. Ingestive behavior and forage intake by beef heifers on tropical pasture systems. Rev. Bras. Zootec., v.42, p.549-558, 2013.

PALHANO, A.N.; CARVALHO, P.C.F.; DITTRICH, J.R. et al. Características do processo de ingestão de forragem por novilhas holandesas em pastagens de capim-mombaça. Rev. Bras. Zootec., v.36, p.1014-1021, 2007. 
PRACHE, S.; GORDON, I.J.; ROOK, A.J. Foraging behaviour and diet selection in domestic herbivores. Ann. Zootech., v.48, p.1-11, 1998.

PRACHE, S.; PEYRAUD, J. Foraging: behaviour and intake in temperate cultivated grassland. In: INTERNATIONAL GRASSLAND CONGRESS, 19., 2001, São Pedro, SP. Proceedings... São Paulo: [s.n.] 2001, p.309-319.

SISTEMA brasileiro de classificação de solos. 2.ed. Rio de Janeiro: Embrapa Solos, 2006. 306p.

SOUZA, A.N.M.; ROCHA, M.G.; PÖTTER, L. et al. Comportamento ingestivo de novilhas de corte em pastagem de gramíneas anuais de estação quente. Rev. Bras. Zootec., v.40, p.1662$1670,2011$.
SOUZA, A.N.M.; ROCHA, M.G.; ROSO, D. et al. Productivity and reproductive performance of grazing beef heifers bred at 18 months of age. Rev. Bras. Zootec., v.41, p.306-313, 2012.

STOBBS, T.H. Rate of biting by Jersey cows as influenced by yield and maturity of tropical grasses. Trop. Grassl., v.25, p.81-87, 1974.

STOBBS, T.H. The effect of plant structure on the intake of tropical pastures. III. Influence of fertilizer nitrogen on the bite harvested by jersey cows grazing Setaria anceps cv. Kazungula sward. Aust. J. Agric. Res., v.26, p.997-1007, 1975.

VAN SOEST, P.J. Nutritional ecology of the ruminant. 2.ed. Ithaca: Cornell University, 1994. 476p. 